of us is perfectly convinced of his own impeccable honesty, but at the same time considers it necessary that his neighbour's honesty should be safeguarded.

This, however, is the only blemish, and it is a slight one. For the rest, the local government is given all the freedom a reasonable local government could ask. It is free to recruit in any manner it pleases, so long as it does so by means of a competitive examination or on the advice of a permanent board of selection set up by itself.

At the same time, the position of an existing servant is safeguarded by the condition that any appointment that would adversely affect him requires the previous sanction of the Governor-General in Council. This very effective safeguard, along with the Orders regulating dismissal, should completely allay the fears which the Indian civil servant has sometimes felt as to the security of his position.

These fears have never been shown by the young men at the British universities who furnish the recruits. The true state of affairs is masked by the fact that at the present time the London competition selects fewer Europeans and more Indians than in pre-War days. Because of this, people jump to the conclusion that our universities are no longer prepared to send their best to India. That is wrong. They send their best to the competition as much as ever they did. The study of the university records of the European Indian civil servants recruited now and before the War shows the standard of the present-day entrant to be fully as high as that of the pre-War entrant. The true explanation lies not in the deterioration of the European condidates, but in the improvement of the Indian candidates.

\section{Scott's Polar Journey and the Weather.}

Scott's Polar Journey and the Weather: being the Halley Lecture delivered on May 17, 1923. By Dr. G. C. Simpson. Pp. 3I. (Oxford: Clarendon Press; London: Oxford University Press, I926.) 2s. $6 d$. net.

$T^{T}$ was natural for Dr. Simpson to choose the subject 1 of Antarctic weather for his Halley Lecture, I923, in view of the important contributions he has himself made to our knowledge of Antarctic meteorology. Dr. Simpson commences with a lucid exposition of the chief meteorological features, with particular reference to the relation between radiation and air temperature, to the formation in the atmosphere of inverted temperature gradients when the sun is low or below the horizon, to the blizzards which disperse the inverted temperature gradients and thus raise the surface temperature, and to the effect of these on sledging conditions, including the friction on sledge runners. $\mathrm{He}$ then reviews the main vicissitudes experienced by Scott on his journey to and from the South Pole, and discusses the importance of the weather in contributing to the disaster which finally overtook the party.

The serious blizzard experienced by the outwardbound party in an unfavourable position at the foot of the Beardmore Glacier delayed them, not only during the time they were laid up, but also on the lower reaches of the glacier, the surface of which became covered with soft snow in which the sledges sank to the cross pieces. This delay was, however, partly offset by bridging of the crevasses with snow. Followed the ascent to the $9000 \mathrm{ft}$. plateau and the traverse to the Pole, the disappointment of finding that Amundsen had forestalled the party, and the return to the head of the glacier. The effort of sledge-hauling at this altitude in a mean temperature (January) of $-19^{\circ} \mathrm{F}$. was undoubtedly tremendous, and the party naturally looked forward to a rise in temperature on descent of the glacier. The temperature did rise, only to fall again before the bottom was reached, and to fall still further as the party, now reduced to four, pushed northwards along the Ross Barrier. At this stage of the journey, Scott met generally light northerly winds, insufficient to blow away the softer surface snow, while the favouring southerly winds for which they prayed were infrequent and not of sufficient force to cause the thorough mixing of the air which would have raised the temperature and improved the surface. These conditions lasted until Oates made the supreme sacrifice, the party falling always further and further behind their time table. Finally, only eleven miles from One Ton Depôt and plenty, the blizzard came, but a blizzard of such strength as to render travel impossible and of such duration (at least ten days) as to cause the final catastrophe. These points are discussed by Simpson in detail and in graphic language.

Scott himself maintained that his arrangements were adequate, and that no one in the world would have expected such conditions so early in the autumn. In his message to the public, he says: "Our wreck is certainly due to this sudden advent of severe weather, which does not seem to have any satisfactory cause. I do not think human beings ever came through such a month as we have come through. . ..." Dr. Simpson makes it clear that conditions were unusual, not indeed in the occurrence of such low temperatures, but in the duration of the cold period unrelieved by blizzards. Herein lay the unforeseen element. Though the onset of the very severe blizzard on March I9 was the actual cause of the disaster, it was, tragically, the absence of blizzards and the consequent intense cold for some time previous to this date which rendered the disaster not only possible, but even probable. 